Original Research Paper

\title{
On the History of Vocabulary Study of Kipchak Languages Group
}

\author{
Lyazat Meirambekova, Gulgaisha Sagidolda, \\ Magripa Yeskeyeva, Tleules Abdygalieva and Karlygash Sarekenova \\ The Faculty of Philology, L.N. Gumilyov Eurasian National University, Astana, Republic of Kazakhstan
}

\author{
Article history \\ Received: 28-01-2016 \\ Revised: 20-10-2016 \\ Accepted: 09-11-2016 \\ Corresponding Author: \\ Lyazat Meirambekova \\ The Faculty of Philology, L.N. \\ Gumilyov Eurasian National \\ University, Astana, Republic of \\ Kazakhstan \\ Email:1meyrambekova@mail.ru
}

\begin{abstract}
The article is devoted to the consideration of the development and formation process of the written Turkic languages from the beginning of the XX century. The research is based on the construction of separate lexicology of Turkic languages on the materials of Kazakh, Kyrgyz, Bashkir, Kumyk, Nogai and Tatar languages. The general lexicological fund of Turkic languages is investigated. The national written traditions of the Turkic speakers' nations, their vocabulary and lexicology formation, the period of their literary national language development are analyzed. Some examples are provided in the given article.
\end{abstract}

Keywords: Lexicological Fund, Development, Formation, Written Kipchak Languages

\section{Introduction}

In the 21 th century the modernization spread broadly in the sphere of informational technology of Turkic nations' cultural relation. It has developed the responsibility to keep ethno-cultural values of Turkic languages in a qualified stage of generalization. There is great modern need in the relationship between Turkic languages and Turkic nations. More than 30 Turkic languages developed from proto-Turkic language as well as independently. Collecting the word value of languages, it has a great importance and there is a need to compose a dictionary of Turkic languages. It has great significance to prove the difference in Turkic languages' lexical fund and the impact of modern social changes on Turkic languages. These important problems are investigating in the field of comparative-synchronous vocabulary construction.

Taking into consideration the genealogic classification of Turkic languages, investigating in- and inter-language group comparative-characteristic analysis or comparative-characteristic analysis of separate languages of other groups constructed the Turkic languages comparative-synchronous lexical lesson's base. This issue has not been investigated previously. However, there is a considerable number of papers on comparative lexical turkology; comparison analysis of two or more Turkic languages in one aspect, namely Kazakh-Turkic, Turkic-Yakut, Tatar-Bashkir, KumykNogai or with other root languages, namely Russian,
English, German etc. In other words, on the basis of information on separate language's lexicology of Kazakh language, the lexicology of Kyrgyz, Bashkir, Tatar languages prove that, there is a need to investigate general lexicological fund of Turkic languages.

In this article, we would like to focus on the word formation of modern Kipchak languages group, namely Kazakh, Kyrgyz, Bashkir, Kumyk, Nogai and Tatar languages. Their modern situations are highlighting the scientific and theoretical significance of this paper.

\section{Material and Methods of the Research}

In this study we used various research techniques to portray an objective picture of the historical reality of the written Turkic languages from the beginning of the XX century and that helped to shape the main reasons for studying lexis of Kipchak languages group.

Key findings of the research were obtained through the use of the comparative-historical and comparative contrastive methods. The use of these research methods is conditioned by the study of information on separate language's lexicology of Kazakh language, the lexicology of Kyrgyz, Bashkir, Tatar languages.

At the same time we used a method of content analysis to examine 6 languages of Kipchak group.

\section{The Result of the Research}

A summary of the progress made in the study of vocabulary of Turkic written monuments: Firstly, the 
general theoretical problems present lexicology of Turkic literary texts written in the XX century II halfformed as a separate subject, developed very quickly to the level of a single Turkic linguistics specially written textbooks and teaching aids, basic vocabulary for high schools, the Turkic language related to the composition of words appear in scientific research; secondly, we note that certain developments in the Turkic lexicology mainly shown in the field of lexicography, lexical richness of Turkic languages has the appearance and was grouped into etymological, intelligent, bilingual, spelling, dialectical dictionaries.

The given investigation broadly shows the national written traditions of the Turk speakers' nations, namely Kazakh, Nogai, Bashkir, Tatar, Kumyk, Kyrgyz and Turk, their vocabulary and lexicology formation, the period of their literary national language development and there are some examples that they have much in common. These languages developed cooperatively, they have constructed as so-called «inter bridge» in broadening the stock exchange of the vocabulary. Significant number of new words appeared in many spheres of everyday life.

\section{Discussion}

\section{Formation and Development of Modern Turk Literary Language}

In their long way of historical development Turkic languages as Tatar, Bashkir, Karachai-Balkar, Crimea Tatars, Karaiym, Kumyk, Nogai, Karakalpak, Kazakh, Kyrgyz and Kipchak languages of Altaic group formed as national literary written languages. Considering the formation of Turkic languages R. Syzdyk noted «The development of nation's literary language is directly concerned with the social history of the nation. The language had been formed since a tribal stage was not the same as it was of the period when these tribes transformed into a nation» (Syzdyk, 2010: 400-412).

The vocabulary of Kazakh, Bashkir, Kumyk, Nogai, Tatar and other modern Kipchak written languages starts its formation from the middle eve manuscripts of the XI century scientists as Mahmud Kashkary «Diuani lugat itturk» (turk dictionary) and Plano Karpini (XIII C.), Gilioma Rubruka (XII C.) and from the old vocabularies of the XVIII-XIX centuries, from the period of Turkic comparative linguistics as a separate subject (The second half of the XIX c.). These researches gave the start to the formation and development of modern Turkic literary written language.

The first information about lexicon of the Kazakh and Kyrgyz languages was published in the XVIII century in P.S. Pallas's «Russian-Kyrgyz dictionary» (1774). The nineteenth century published A. Levshin's «Description of the Kyrgyz-Kazakh or Kirghiz-Kaisak hordes and steppes», N.I. Ilminsky «Materials for the study of the Kyrgyz dialect» as well as the grammar of the Kazakh language of the P.M. Melioransky, V.V. Radlov, etc. in the writings of Turkologists. Budagov (1869), the two-volume «Dictionary of Turkic and Tatar comparative Dictionary» the words of the Kazakh analyzes. The lexics of Kumyk vocabulary compared with other Turkic words of the famous German traveler and explorer in the early nineteenth century G.Y. Klaprot's «Reise in den Kaukasus und nach Georgien in den Jahren 1807 und 1808» (I-II, Halle and Berlin 180708). Given a well-known work has become a science for the benefit of a great scientific achievement in the history of the study of the language of the Kumyk is a translator and language teacher of Kumyk's T.N. Makarov wrote in 1848 on the basis of Kumyk spoken language «Caucus grammar of the Tatar dialect» in the same period, at that time «Tatars of the Caucasus called the Turkic» people. Here is a rich visual material in Russian language translation of Kumyk.

Kumyk language models, the first notes of the 70 years of the XVIII century. These Bakmeyster linguistic materials are collected and later an honorary member of the Academy of Sciences of the Adelung (1815) of the P.S. Pallas is part of a number of materials. Bakmeyster, Adelung, Pallas archived and related material, especially the Turkic language "Comparative dictionary of all languages and dialects» (1787-1789) may serve the purpose of comparative historical lexicography. K.G.Zaleman recorded in the form of a copy of the A.Shifner Russian-Kumik vocabulary, as well as K.G. Zalemanin created by the student's life (1867-1871) «Russian-Kumyk dictionary». It is important to research the history of the vocabulary of the language of Kumyk (Dmitriyev, 1949: 183-247).

Bashkir state became part of Russia, the Bashkir vocabulary became the credentials of the Russian language at a later stage. For example, P.I. Rychkov Lexicon or Dictionary topographic Orenburg province» (Rychkov, 1776). Dictionary of names of many of the Bashkir explanation or translation: Yamantau from Yaman «bad, worst», Aktau-White Mountain, Kizlyartau-Maiden mountain Iryak-tash-Osokorevy Stone etc. (Rychkov, 1762: 595). Developed the leadership of the guidance of Academician P.S. Pallas «Comparative Dictionaries of all languages and dialects collected by the right hand of the Highest Mark lady» (1787) reflected in the dictionary there are 200 word vocabulary material between 285 Bashkir and the Orenburg province office of the college court Bashkir official M. Bichurin developed «Bashkir language translation of the word» ( 80 years of the XVIII century) manuscripts 360 Russian Bashkir translation of the word is given in (Kissamitdinova, 2011: 12). P. Utsadamtsev developed «Tatar, Bashkir, Kalmuk language translation of the word list» is the original manuscript of the 
dictionary. The amount of three hundred fifty seven Russian words is translated into the languages of the above. In1899 V. Katarinskiy semantic and grammatical features groupings in 2500 about Bashkir words «Bashkir-Russian dictionary» announces. This dictionary is the practical value of the study of the prerevolutionary Bashkir and Russian languages and is considered to have an important place in the Bashkir lexicography work (Kononov, 1982: 257).

One of the most significant works in the Turkology in XIX-XX century is published by Budagov (1869) «Comparative dictionary of Turkic-Tatar adverbs with addition of Arabic and Persian words with translation into Russian», second work is published by the academic B.B. Radlov «Experience of Turkic adverbs». There are 200 words in first book, 50 Bashkir words in the second language. There are nearly 200 Bashkir words in the work of M. Bichurun «Bukhars, Bashkirs, Kyrgyz and first book on learning Arab, Persian, Tatar languages for nation of Turkistan» (Kissamitdinova, 2011: 29).

The lexicology of Kazakh language established in the middle of the XX century today etymology, historical lexicology, terminology, onomastics, phraseology, lexicography are important part of Kazakh language. In this field of study G. Begaliev and N. Sauranbayev published a book «The grammar of Kazakh language» for pedagogic institute.

From the second half of the XX century the lexicology of Kazakh language developed dramatically. The general aspects of Kazakh lexicology are seen on the works of Akhanov (1996; Mussabayev, 1978; Kaidarov, 2009; Syzdyk, 2010; Tomanov, 1981; Orazov, 1991; Aigabilov, 1995; Kajibekov, 1986; Tumebayev, 2005; Mankeeva, 1997; Janpeissov, 1976; Shoibekov, 1993). The Kazakh language's historical lexicology is investigated from the etymological point. Amanjolov (1996; Aidarov, 1995; Sartkozha, 2003; Yeskeeva 2007) old Turkic written monuments language, Abilkhasimov (2001; Ibatov, 1990; Kuryshzhanov, 1998; Sagyndykov, 1994) middle century Turkic written value`s language, Abdirakhmanov (1986; Zhanuzakov, 1982; Sultanayev, 1990; Kerimbayev, 1995; Rysbergenova, 1993; Tyleuberdiev, 2005; Madieva, 2010) Kazakh onomastic, Aitbayev (2000; Kurmanbay, 2002) Kazakh terminology, Malbakov (2002) lexicology, Satenova (1997; Sagidolda, 2003) outstanding works in phraseology are important in Kazakh lexicology.

In the second half of the XX century, a number of works with a great significance appeared in Kazakh lexicology. That is to say, Sauranbayev's RussianKazakh Dictionary (1954), Orthographic Dictionary of Kazakh Language (1963). G. Musabayev's RussianKazakh Dictionary (1978), Ten Volume of Kazakh Explanatory Dictionary (1974-1986), Kenesbayev (1977) Phraseological Dictionary of Kazakh Language which include more than ten thousand phraseology, The Dialectological Dictionary of Kazakh Language (1996) and many other dictionaries. All these are a great success of Kazakh Lexicology. While A. Kaidar's In the World Of Kazakh Mother Tongue, which almost systematically included all the Lexico-Phraseological units in Kazakh language and tried to explain the meanings of all of them is the work which shows the development of Kazakh Lexicology in the first years of the XXI century (Kaidarov, 2009: 780).

The formation of Kyrgyz Lexicology as an independent branch of linguistics happened in the Soviet time of the Kyrgyz people. K. Tynystanov who made a series of school textbooks made a great contribution to this development. In these textbooks, the oral lexicons of Kyrgyz people appeared in the new written forms in Arabic scripts which were merely reformed.

In studying the Kyrgyz linguistics, specially its lexicology, I.A. Batmanov's research in comparing Kyrgyz language with Siberian region Turkic languages, Kyrgyz lexicology with lexicology of Enisey monuments, Altaic, Tuva, Hakas and Shor had a great significance (Batmanov, 1959: 219).

It is important to mention the Kyrgyz-Russian Dictionary composed by Iudahin (1940, 1965). The dictionary which included almost forty thousand words presents terms of all human professional activities and word depicting the political-economic, social-cultural and scientific life of Kyrgyz people in the middle of previous century. K.K. Iudahin made foundation of Kyrgyz Lexicology and Lexicography through this work, said (Sartbayev, 1970: 3-15). B. M. Iunusaliyev studied Kyrgyz lexicology from the perspective of development of root words (Yunusaliev, 1959: 246). Kyrgyz lexicology is also discussed in Zh. Mamytov, Z. Kulumbayeva, T.A. Akhmetov and Zh. M. Mukambayev, A. Zhalilov's works (Karbozova, 2015).

Although A. A. Satybalov made the foundation of Kumyk Lexicology in 1930s, (Essays on the vocabulary and semantics of the Kumyk language), it became an independent subject in the second half of the XX century. The ancient lexics of Kumyk language was studied in «About original Kumyk language vocabulary» by Kadyradzhiyev (1981). The kinship names were studied in the History of Kumyk Lexics by Levitskyi (1973). The Polysemy in nouns and verb system were studied in Kumyk Language by Baturmurzayeva (2002). Lexical Synonyms were studied in Synonyms and Synonymous relations in the Kumyk language lexics by Dzhalilova (2003). The types of Homonyms and semantic relations about them were studied in homophones in the Modern Kumyks Language by Beshirov (2002). The archaic words and historical lexics in Kumyk language were studied in Old Lexics of Kumyk Language by Asadulayeva (2013). Emotive 
lexics were studied in Elmurzayev (2009) emotives in lexics of Kumyk Language. The religious words were studied in Yakhyayeva (2010) religious Lexics and Phraseology of Kumys Language. The Houshold lexics were studied in Abdullayeva (2012) Houshold Lexics of Kumyk Language.

The examination of the lexicology of Bashkortostan is closely conected with the name of $\mathrm{Zh}$. G. Kiekbayev. His concept of Bashkirian lexycology development is reported in the book, which is called «Lexycology and phraseology of the modern Bashkirian language». In this work, the theory commonality between Baskirian and Ural-Altaic languages were described for the first time, borrowed words from Arabic and Persian languages were individually analyzed and semantic-stuctural components of the Bashkirian dictionary were examined (Mamytov and Kulumbayeva, 1971: 112).

There are many bashkirian dialectologists, who made significant research work on languages investigations. For instance, T.G. Baishev examined the tasks and relation between dialects and literal language. N. Kh. Ishbulatov worked on comparatively exploringBaskirian dialect vocabulary with materials in Fin-Ugorian languages (Akhmatov and Mukambayev, 1978: 176).

Objectives of the historical lexicology were comprehensively studied in research works of E.F. Ishberdin's «The historical development of the vocabulary of the Bashkir language» (1986), M.Kh. Akhmart's «The verb in the language of Orkhon-Yenisey monuments (in comparative terms with the modern Bashkir language)» (1978), T.G. Garipov's «Kipchak languages of the Ural-Volga region. The experience of synchronic and diachronic characteristics» (1973), R. Kh.Khalikov's «Language Bashkir shezhere and assembly documents of XVIII-XIX centuries» (1990) and onomastic lexicon was considered in A.A. Kamalov, T.Kh. Kusimova, F. G. Khisamitdinova, M. G. Usmanova, P. Z. Shakurov and Z. Shaikhislamov's works.

In the last 40-50 years along with bilingual dictionaries in the Bashkir language proficiency semasiological characterization and formation of words was made lexicographical work and different dictionaries such a dictionary of synonyms (Uraksin, 1966; 1985; 2000), homonyms (Akhtiyamov, 1966; 1986), antonyms (Akhtiyamov, 1973, 2009), paronyms (Ishbaev and Ishkildina, 2001), phraseological units (Uraksin et al., 1973, 1989, 1996, 2006), morphemes (Akhtiyamov et al., 1992, 1994, 2004, 2005, 2008). Onomastic collection of materials: A dictionary definition of proper names (Kusimova and Bikkulova, 2000; Khisamitdinova and Sultanoa, 1982, 2000; Tupeev; 1976, 1991), toponym dictionaries (Kamalov, 2000; Shakurov et al., 1980, 1992, 1994, 2001, 2002, 2005, 2006, 2008, 2009); had appeared ideographic type of new dictionaries: ideographic (Usmanova, 2005).
Mainly to the national tradition of the era of the written language of Turkic people are common to all. There is an investigation of the development of good oral speaking and folklore for centuries developing each of the Turkic languages written in wedge-Yenisei monuments Orhon-Talas ancient Turkic written language (VI-VIII centuries), the language of medieval Turkic monuments (XII-XVI centuries), then in other periods territorial division meets both language feature called «Chagatai language» is the official language of the Central Asian Turkic, Tatar khanate, used this language Turkic Golden Horde Volga-Ural Turks after they became separate nations of their official papers, literature, historical works adapted to write different versions such as the ancient Kazakh, ancient Uzbek, ancient Tatar originate from Turkic written language.

The present Turkic written languages are those languages which in terms of graphics are the exact brand of writing, extensive public social job horizons, divided by style points and improved on a level developing oral and written forms of language. These languages include the breeding of the western branch of the Turkic languages: Relating to a group of Bulgarian Chuvash language; components Oguz group of Azeri, Gagauz, Turkmen Turkic languages; components Kipchak groups of Tatars, Bashkirs, Karachay-Balkar, Crimean Tatars, Kara, Kuruk, Karakalpak, Kazakh languages; components of the Karluk group of Uzbek and Uighur language, included in the group of the western branch Uighur, Ogyz, Tuva, Yakutia, Hakaskia languages; constitute a group of Kyrgyz-Kipchak include Kyrgyz and Altaic languages (Ramstedt, 1957: 192).

The current Turkic written language in twentieth year of the XIX century of the state of Turkey was held to the policy language, including has been closely linked with the reform that has been done on the alphabet in 1928 and which subsequently developed. Adopted a new alphabet which was based on the Latin alphabet completely changed the system from outdated language input elements using the internal capabilities of the Turkic language and vocabulary related languages, the emergence of new names in this basis, supplemented by a wealth of Turkic language dictionary, a grammar that is fully consistent with the original reality Turkic language, the creation of textbooks and teaching aids, to differentiate and complement the richness of Turkic language through word of dictionaries, history and dialectology of Turkic language, undertake thorough study of written monuments of the Turkic language and other related activities carried out comprehensively led to a positive impact of the current development of the Turkic national writing literary language.

Turkic people as distinct ethnic groups, each formation and then to the languages in common Turkic languages record souvenirs, as well as recording a new 
era of national literary languages (treasure words, grammatical structure, sound system) and various historical and position period status research in general, very wide and, of course, a serious problem. However, level of spoken and written language models for each sub-system in terms of various aspects of language linguistics was established to review the methodological approach, Turkic treasury will be allocated for research in the field of linguistic Turkic lexicology.

\section{Turkic Languages Have Vocabulary Stratigraphic Layers: General Altaic and Turkic}

Kazakh, Kyrgyz, Bashkir, Nogai, Tatar and Kipchak languages chronological structure of the genetic point of view, such as: (1) Turkic, Mongolian and Manchu language show genealogical layersof the given languages; (2) consisting of common words in Turkic languages which is describes as Turkic layer; (3) Life for each of the Turkic people's knowledge of the nature and culture of the ethnic identity of the indigenous own vocabulary layer; (4) Turkic people of historical and cultural ties with other nations in the access layer, which can be divided into four stratigraphic layers.

General Altaic layer Turkic languages many words Altay direction of experimental studies, which will be considered in the context of the root. For example, the root of the Altaic languages pilot words (elementary, primary) comparativical research Turkic-Mongol, Turkic and Mongolian-Tungus-Manchu and Mongol-TurkicTungus-Manchu languages in parallel, with special emphasis on the point of view that is similar to the sound of the verbs:

- Turkic. ora- 'packaging, faster check-out, fraud', 'cause': the Turks. ora, Oct. ora-, UZB. ora-, Dial. horä-, uyg. oru-, lobn. ojo-, çwv. văr- 'packaging', 'cause-and-drop', 'ask around' - medium-mong. horči-, mong. Samuel orči- 'rotation', orija-, oruya'turning around, cause-and-drop', H.-moñğ. orō-, orči-, drill. oŕō-, oršo-, Calm. orā-, orčă-, dwns.

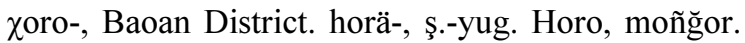
furō-, $\chi$ urō 'packaging, packing and drop' tuñğ. mançj.: Event. horol- 'rotation, rotation' money.

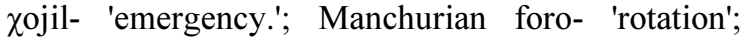
'something fast circuit; ulch.. pori- 'mesh weaving

- Turkic. as- 'hang': Turk. as-, goose. as-, xaladj. has-, khalaj. us- 'hang' writing. mong. asa-, H.-mong. asa-, drill. aha- 'climb up, climbing,' auger. ahā'registration, strap, to hang exceed' tuñğ. mançj .: oroç. $\chi$ asi, bread. hasi, fasi-, bread. orok. pasi'implementation, hang on

- Turkic. Üskür- 'spell', 'spray (spittle) “: Turk. Üsgür, xaladj. Esür, Turkey. Öksür-, gag. Üsür-, Chuv. Üzěr-' cough ',' cough 'üslěk Mong.'spray, spraying "Hösür-: Mong record. ösür-, üsür-, H.-

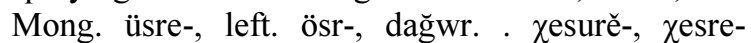
"spray" writing mong.: Event. husu-, news. hus-, money. ұusi-, mançj. fisi-, fise-, fusu-, ulch. pisuri-, bread. pisi-, fisi-, nan. pisitči-, possoli- "injection"

The Turkic language of the Turkic layer forms the core of the modern Turkic languages lexical fund. The Turkic word in the ancient and medieval monuments, as well as large and almost all central words from Turkic languages. For example:Orkh., E., Tal. Jil "year" Bashk. zïl, sand., Rust, legs. Jil; Orkh., E., Tal. Jim (saq) "soft" rust. q.tat. Jim dialects (Saq), in the snow. Tal. (saxophone), kkarak. dïm(saq); Orkh., E., Tal. jis "dense, forest, rabble" $\sim$ kkarakalp. žïs, rust. Bashk. žǐs, Kyrgyzstan. dïm. Kazakh language žïnïs "thick, dense" is related with lexeme of the ancient Turkic word jiš; Orkh., E., Tal. Jiš «girl, girl, daugther» kaz., kkarak., nog., kum., bashk. Qizz; Orkh., E., «shorten, cut» kaz., kkarak., nog. Qiis(qa)"Short, concise"; Orkh., E. qïl «make» kaz., kkarak., nog., qül,kyrg., bashk., tat., kïl; Orkh., E., Tal. Qürq «fourty» kaz., kkarak., nog. Bashk; qürïq; tat., kyrg. kïrk; Orkh., E., Tal. qïs «winter» kaz., kkalp., nog., kum. qüs, tat., bashk., kyrg.

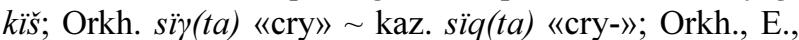
Tal. tïn,la) «listen» kaz., kkalp., nog., bashk. tïn (da)/tïn(la).

Many of the Turkic languages lexical semantic approach is the same, but only the Turkic language to language groups, separate languages, distributed in accordance with the laws of the individual and group of languages, their phonetic, morphological and personality traits may occur. For example, consonants in the Turkic languages $\mathrm{Q}, \mathrm{K}, \mathrm{Y}, \mathrm{G}, \mathrm{X}, \mathrm{H}$ sounds phonemes of the Turkic languages, such as the development of the ancient era, one allophonesof phonemes were so close to each other in terms of genesis, related sounds are considered (Baskakov, 1988: 105).

Common consonants in the Turkic languages, the languages of the various factors developed specific properties. Formed from by only one sound and affricates spread from the general appearance of Q, K, $\mathrm{Y}, \mathrm{Z}, \mathrm{R}, \mathrm{H}$ changes of allophones into individual phonemes as a result of long-term chronic phonologization; articulation, acoustic features of formation carried within the process of linguistic evolution, physio evolution. For example:

$\mathrm{Qq}$ (city) the lower part of the tongue to touch the back of the palate, the name of an emergency simply phonemes. The q sound at the end of words in most of the Turkic languages, including ancient Turkic language, kaz.tat. nog., bashk., kyrg.,uyg.,turkm., tuv. languages aq, uzb. language-oq"white" in ancient Turkic language, kaz, tat, kumk, tuv. - in balk, kyrg, tuv .. languages balik "fish". 
Each of the features of the language at the end of a word sound forth a few changes: 1. $\mathrm{q} \approx \mathrm{x}$ (yak. - suox, atax, ox; khakh. - ajax, čox; azerb. - jox, ox; kaz. -ajaq, žoq, oq "leg", "bullet", "no"); 2. q g (azerb. - balig;

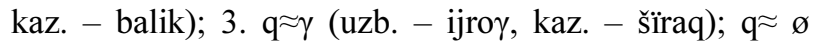
(chuv. - ura, čere, pure; kaz. - ajaq, žürek, büjrek). q $\approx$ xis in accordance with the Mongolian languages: ancient Mongolian language-AQA, Mongolian yeah; October Yeah, "the elder." Some of the Turkic languages consonant $\mathrm{n}$ junction a little different, for example, E.R. Tenisheva shows, old Uighur, Yellow uighurs languages hoarsely sound (aqh; "(verb)" kaz, Ak) (Tenishev, 1963: 125).

Providing modern Turkic languages, the sound data corresponds to the VII and IX century Turkic language Orkhon, Yenisei and Talas record is seen as the language of the main stem. Changes in the monuments of the language and voice language Kipchak Turkic general vocalization difficult path of development, the direction of the development process, Kipchak group, each of which refers to the characteristics of the ancient Turkic language and degree of linguistic phenomena. Orkhon, Yenisei and Talas inscriptions and of the Kipchak monosillables the legitimacy of natural language voice coincidence. Monuments eight vowels in modern Turkic languages, including the languages of Kipchak fundamental right to vote in the system. For example, Spanish Kipchak monosyllables or polysyllabic words in the first two generations of vowels is one of the first voices. A.M. Sherbak Tuva, Yakuts sound from the point of view of a ancient vowels that Turkic influence on the formation (tip "faind" < faucet, Killeen "thick" < Kalin, IL "Brother" < and Mimir "root", "vein" < Mamir, Mij "vtoromw foal of the year with" < Major, etc.) and say "change the sound of the sound I Turkic nature ancient one language dialects" conclude (Sherbak, 1994: 145). Changes in the volume of the monumental language that modern languages Kipchak systematically property, relations includes only the word of two or three of each, in other words, vowels are full compliance.

The old record for an inheritance in the words of one syllable vowel of Kipchak language group does not change.

\section{Anlaut}

Orh., E., Tal. il(gerü) kaz. . il (geri); Orh., E., (il)ki, Orh. "go down" kaz. in, en "enter", bashk. ijn(ergä) "enter", kum. ijn "hole”, nog. ijn, kyrg. ijin; Orh., E., Tal. Ini "brother " kaz., kkalp. ini, kum. ijni, kyrg. ijni; nog. ijni; Orh., E., is "work" kaz., kkalp. is, tat., Orh., E., Tal., $i \check{c}$ “in", $i \check{c}(r e)$ "inside" $\sim \operatorname{kaz} i \check{s}$, kum. ijč, nog. ijš, kyrg. ijč.

\section{Inlaut}

Orh., E., Tal. Biz "we" kaz., kkalp. biz, kum. bijz, kyrg. bijz, nog. bijz; kum.bijl; Orh., E., bin "climb" kaz., kkalp. bil, nog. bijl(uv), kum. bijl, Orh., E., bin "climb" kaz., kkalp. min, kyrg. mijn; Orh., E., bir/ber kaz., kkalp. ber(iw), nog. ber(uv), kum. ber(mek); Orh., E., Tal bir “one” kaz., kkalp. bir, nog. bijr, kum. bijr; Orh., E., bis/beš "five” kaz., kkalp. kaz. žit; Orh., E., Tal. ji(ti)/je(ti) "seven” kaz. zeti, nog. jeti/žeti; Orh., E., Tal. kim "who?” kaz., kkalp. kim, nog. kijm Orh., E., Tal. kič(ig) "little" kaz., kkalp. kiši, nog. kijšs(kej), kyrg. kijč(ijne); Orh., E., Tal. siṇ(ili) "sister" kaz., sin(ili), bashk. heņ(le), kyrg. sijn(dij); Orh., E., Tal. siz "you", bashk. hijz/hez, nog. kum. kyrg. sijz; Orh. tik "sew" kaz., kkalp. tik, nog, kyrg, tijk; Orh., E., Tal. tir(ig) “alive” kaz., kkalp. tir(i); Orh., E., tiz "knee”, kaz., kkalp. tiz(e)/diz(e).

\section{Auslaut}

Orh., E.,Tal. $t i$ "say, tell" kaz., kum., nog., kkalp., de; tat. dij, bashk. tij. Vowel $\mathrm{i}$ in the content of monosyllables in the language of monuments are used with some similarities in Kipchak languages.

The vocabulary of all Turkic languages was changed because of the development of all languages, extending and narrowing of the area of using the language changed the meanings of the words. Their first meaning which helped the development of the semantic meaning of the word is rarely shown in the vocabulary. Compare: chuv. tavăr-, tat. tägärä-, yak. tägir $\bar{l}$-, ancient Turkicmegirä “area, environment”, tegir-män "mill”, Turkmentegelek "round", nog. togin "round", tat. dugim, chuv. togăm "round", shagat. toy-lak "rouned", tel. toyolok, kaz.

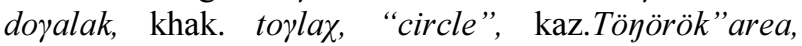
environment", töygülök "circle”, tob.tüyäläk "ring, circle"; turk. pèli- $\eta$ (- $\eta$ ending to make noun from verb):ancient.- uyg. beliy "timid", ancient.- uyg., shagat. balinla- "to wake up in a fright", teleut. pelindä"timidous"; ancient-turk. belin "fright"; turk. belin "astonished"; dial. belin "rabbit", kaz. beley "nervous", beley al- "nervous" (about horses) (Doerfer, 1976: 81-131).

\section{Conclusion}

In the lexical research such languages as Kazakh, Kyrgyz, Bashkir, Kumyk, Nogai and Tatar written languages have taken their root from the outstanding work on Turkic nations' languages, which is written in the XI century by Makhmud Kashgary`s «Diuani lugat at-Turik» dictionary. Mostly information is taken from nations of these languages and their hand scripts of tourists, missioners' of that time about these languages (middle of XIX century).

The time of formation of the national written literary language of Turkic languages are continuous with each other. For example, the second half of the XIX century Kazakh and Turkmen languages, the end of the XIX century and early XX century the Turkic language, the end of the quarter of the XIX century the Azeri language, twentieth year of the XX century the Kirghiz, Bashkir, 
Nogai and Kumyk languages, fiftieth year of the XX century emerged as the Gagauz language national language and literature written in the XX century up to the level of quality of the new development.

As to form Kazakh, Kyrgyz, Bashkir, Kumyk, Nogai, Tatar and Kipchak written language' words were classified into chronologic-genetic aspect:

- General Altaic layer of Turkic-Mongol and TungusManchu language`s genealogic root

- General Turkic layer with the common lexis

- Old Lexics layer with the difference of Turkic nations` languages separately and ethnic, cultural root

- Mutual layer with the connection of Turkic nation with other countries

Lexis are the fastest acceptable part of social changes of the language, Kazakh, Kyrgyz, Bashkir, Kumyk, Nogai and Tatar languages word values contain General Turkic layer word value. General Turkic lexical layer of Turkic languages, general Altaic layer and every Turkic language`s old lexical«bridge» function are changed in constructing the root in new words.

The result of the research suggested further development and study of material base and theory of large lingua groups belonging to Turkic language family, namely Bulgar, Karluk, Kipchak, Oguz and such sub-groups as Oguz-Selzhuk, Kipchak-Oguz, Kipchak-Nogai and Kyrgyz-Kipchak their comparativehistorical and other characteristic features necessary for further research, theory courses and seminars on modern Turkic languages.

\section{Acknowledgement}

The researchers would like to express their gratitude to L.N. Gumilyov Eurasian National University for financial support.

\section{Author's Contributions}

All authors of this research article have directly participated in the planning, execution and data analysis and manuscript preparation.

\section{Ethics}

This article is original and contains unpublished material. All of the authors have read and approved the manuscript and no ethical issues involved.

\section{References}

Abdirakhmanov, A., 1986. Problems of onomastics in Kazakhstan, Almaty: Nauka, pp: 132.

Abdullayeva, 2012. Houshold Lexics of Kumyk Language.
Abilkhasimov, B., 2001. Abilgazy Khan's «The Turkic shejire and its language». 1st Edn., Almaty: Aris, pp: 243.

Adelung, F., 1815. Catherinens der Grossen Verdienste um die vergleichende Sprachkunde. 1st Edn., St.Petersburg. pp: 178.

Aidarov, G. 1995. Kultegin Monument. 1st Edn., Almaty, Ana tyly, pp: 232.

Aigabilov, A., 1995. Kazakh language morphonology. Almaty, Sanat.

Aitbayev, O., 2000. Basics of Kazakh Terminology. 1st Edn., Almaty, pp: 148.

Akhanov, K., 1996. The theory of grammar. Almaty, Sanat.

Akhmart, M.K., 1978. The verb in the language of Orkhon-Yenisey monuments (in comparative terms with the modern Bashkir language).

Akhmatov, T. and Z. Mukambayev, 1978. Phonetics of Kyrgyz Language. 1st Edn., Frunze, pp: 176.

Akhtiyamov, M.K., 1966, 1986. Homonyms Dictionary of Bashkir Language. 1st Edn., Ufa, pp: 137.

Akhtiyamov, M.K., 1973, 2009. Antonyms dictionary of Bashkir language. Ufa.

Akhtiyamov, M.K., Urazbayeva, Z.G., Hisamitdinova, F.G. and Ishegulova A.M., 1992, 1994, 2004, 2005, 2008. Academic Dictionary of Bashkir language. Ufa.

Amanjolov, A., 1996. The History of Turkic Philology and Script. 1st Edn., Almaty, Sanat, pp: 127.

Asadulayeva, P.U., 2013. Old Lexics of Kumyk Language.

Baskakov, N.A., 1965. The History of Learning Turmen Language. 1st Edn., Ashkhabad, pp: 35.

Batmanov, I.A., 1959. The Language of Enysei Monument Os Old Turkic Nations. 1st Edn., An Kyrgyzstan. pp: 219.

Baturmurzayeva, U.M., 2002. The Polysemy in nouns and verb system in Kumyk Language.

Beshirov, B.S., 2002. The homophones in the Modern Kumyk Language.

Budagov, L.Z., 1869. A comparative dictionary of TurcoTatarian adverbs. Volume I. Saint Petersburg, Volume II, 1971, pp: 414.

Dmitriyev, N.K., 1949. Materials of Kymik language. Languages of Northern Kaukaz and Dagestan, 2: 183-247.

Doerfer, G., 1976. Vorosmanishe (die Entwickung der oghusischen Sprahen von den Orchonschriften bis zu Sultan Veled)//Türk Dili Araştırma Yıllığı. Ankara.

Dzhalilova, P.I., 2003. Lexical Synonyms in the Kumyk language lexics.

Elmurzayev, E.M., 2009. Emotives in lexics of Kumyk Language.

Garipov, T.G., 1973. Kipchak languages of the UralVolga region. The experience of synchronic and diachronic characteristics. 
Ibatov, A., 1990. When is the Kazakh language appeared? Almaty, Zerde. № 11.

Ishbaev, K.F. and Z.E. Ishkildina, 2001. Dictionary Paronyms Bashkir language. 1st Edn., Ufa, pp: 312.

Ishberdin, E.F., 1986. The historical development of the vocabulary of the Bashkir language.

Iudahin, K.K., 1940, 1965. Kyrgyz-Russian Dictionary.

Janpeissov, E., 1976. M.Auezov's epic language in the poem «Abai's Way». Almaty, Science.

Kadyradzhiyev, K.S., 1981. About original Kumyk language vocabulary.

Kaidarov, A.T., 2009. In the World of Kazakh Mother Language. 1st Edn., Almaty, pp: 780.

Kajibekov, E.Z., 1986. Verbal and Nominal Correlation of Homogeneous Roots in Turkic Languages. 1st Edn., Almaty, Nauka, pp: 270.

Kamalov, A.A., 2002. Dictionary of Names of the Republic of Bashkortostan. 1st Edn., Ufa, Kitap, pp: 253.

Karbozova, K., 2015. Research of structure and semantic meanings of homonymous units. The Social sciences, Medwell journal, Pakistan.

Kenesbayev, I.K., 1977. Phraseological Dictionary of Kazakh Language. Almaty.

Kerimbayev, E., 1995. Kazakh onomastics in ethnocultural, nominative functional aspects. Almaty, Science.

Khalikov, R.K., 1990. Language Bashkir shezhere and assembly documents of XVIII-XIX centuries.

Khisamitdinova, F.G. and R.I. Sultanov, 1982, 2000. Russian-Bashkir Dictionary catalog of personal names and surnames. Ufa, Kitap.

Kissamitdinova, F.G., 2011. Academic dictionary of Bashkir language. Ufa.

Klaprot G.Y. «Reise in den Kaukasus und nach Georgien in den Jahren 1807 und 1808» (I-II, Halle and Berlin 1807-1808).

Kononov, A.N., 1982. History of learning Turkic languages in Russia. 1st Edn., Science, pp: 360.

Kurmanbay, B. 2002. The Nature of the Kazakh Terminology Development Stage. 1st Edn., Astana. pp: 184.

Kuryshzhanov, A., 1998. Moiyn-Chur Monument. Kazakh language. Encyclopedia, Almaty.

Kusimova, T.Kh., Bikkulova. A. 2000. Bashkir names. Ufa, Kitap.

Levitskyi, L.S., 1973. Historical morphology of the Chuvash language. Moscow.

Madieva, G. 2010. From the history of onomastics. Almaty, Science.

Malbakov, M., 2002. Structural bases of explanatory dictionaries, Almaty: Gylym.

Mamytov, Z. and Z. Kulumbayeva, 1971. The First Step to Kyrgyz Language. 1st Edn., Frunze, pp: 112.

Mankeeva, J., 1997. National Identity of Cultural Lexicon. 1st Edn., Almaty, Gylym, pp: 45.
Musabayev, G., 1978. Russian-Kazakh Dictionary Almaty. Mussabayev, G., 1978 Russian-Kazakh Dictionary Almaty. Orazov, M., 1991. Kazakh language semantics. Almaty: Ruan.

Orthographic Dictionary of Kazakh Language. 1963 Almaty.

Ramstedt, G.J., 1957. Einführung in Die Altaische Sprachwissenschaft. 1st Edn., Helsinki, pp: 192.

Rychkov, P.I., 1776. Lexicon or Dictionary topographic Orenburg province.

Rychkov, P.I., 1762. Lexicon or Dictionary topographic Orenburg province. 1st Edn., Petersburg, pp: 595.

Rysbergenova, K., 1993. Historical and linguistic analysis of toponyms of South Kazakhstan region (based on the western areas). Almaty, Science.

Sagidolda, G., 2003. Ethnic and cultural content of the poetic phraseology. Almaty, Science.

Sagyndykov, B., 1994. The Etymological Basis of the Kazakh Language Vocabulary Development. 1st Edn., Almaty, Sanat, pp: 166.

Sartbayev, K.K., 1970. Turkic Investigations. 1st Edn., Frunze, Ilim, pp: 15.

Sartkozha, K., 2003. Orkhon Heritage. 1st Edn., Astana, Kultegin, pp: 392.

Satenova, S., 1997. The linguistic and poetic nature of phraseology in Kazakh language. 1st Edn., Almaty, pp: 260.

Sauranbayev, N., 1954. Russian-Kazakh Dictionary Almaty.

Shakurov, R.Z., M.F. Uraksin, F.G. Khisamatov, Z.A. Khisamitdinova and N.F. Sirazitdinov et al., 1980, 1992, 1994, 2000, 2001, 2005, 2006, 2008, 2009. Russian-Bashkir Dictionary. Ufa, NO "Bashkir Encyclopedia".

Sherbak, A.M., 1994. Introduction to Comparative Learning of Turkic Languages. 1st Edn., St. Petersburg, pp: 191.

Shoibekov, R., 1993. Kazakh art vocabulary. Almaty.

Sultanayev, O., 1990. Turkic onomastics. Prospects and development. Almaty, Science.

Syzdyk, R., 2010. The history of Kazakh language. Pavlodar.

Ten Volume of Kazakh Explanatory Dictionary. 19741986. Almaty.

Tenishev, A.R., 1963. System of Yugur Language. 1st Edn., Baku, pp: 125.

The Dialectological Dictionary of Kazakh Language. 1996. Almaty.

Tomanov, M., 1981. Historical grammar of Kazakh language. Almaty, Mektep.

Tumebayev, J., 2005. Kazakh-Mongolian lexical parallels: Contributions to the etymological dictionary of the Kazakh language. Moscow.

Tupeev, S.K., 1976, 1991. Directory of personal names with spelling variants in Russian and Bashkir languages. Ufa. 
Tyleuberdiev, B., 2005. The linguistic image of the scientist in Kazakh onomastics. Kazakh language and literature. Almaty, Science.

Uraksin, Z.G., 1966, 1985, 2000. Phraseological synonyms in Bashkir language. Ufa.

Uraksin, Z.G., 1973. Bashkir Russian Phraseological Dictionary. 1st Edn., Moscow, pp: 404.

Uraksin, Z.G., F.A. Nadrshina and K.G. Yusupov, 1973, 1989, 1996, 2006. Bashkir-Russian phraseological dictionaries. Ufa.

Usmanova, M., 2005. Thesaurus as a reflection of the systemic organization of language and its role in learning and enriching vocabulary. Access.

Yakhyayeva, Z.B., 2010. Religious Lexics and Phraseology of Kumyk Language.

Yeskeeva, M., 2007. Monosyllabic Basis of Ancient and Modern Kipchak Languages. 1st Edn., Almaty, Aris, pp: 360 .

Yunusaliev, B.M., 1959. Kyrgyz lexicology.

Zhanuzakov, T., 1982. Essay of Kazakh Onomastics. 1st Edn., Almaty, Science, pp: 173.

\section{Abbreviations}

\section{Monuments}

$\begin{array}{ll}\text { EK } & \text { Bylge kagan } \\ \text { E } & \text { Enysei scripts } \\ \text { KT } & \text { Kultegyn, great script } \\ \text { KTs. } & \text { Kultegyn, small script } \\ \text { KCh } & \text { Kuli Chor monument } \\ \text { MCh } & \text { Moiun Chor monument } \\ \text { On. } & \text { Ongyn monument }\end{array}$

Orkh. Orkhon scripts

Tal. Talas scripts

Ton. Tonykok monument

Sh. Shu scripts

YB Yryk Bytyk

\section{Languages}

alt. Altay

azerb. Azerbaizhan

bash. Bashkir

o.kup. Old Kipchak

k.bal. Karashai-balkar

kaz. Kazakh

kar. Karayim

kkhal. Kara kalpak

k.tat. Kyrym Tatarlary

Kym. Kymik

kyrg. Kyrgyz

mazh. Mazhar

mong. Mongol

nog. Nogai

uzb. Uzbek

tat. Tatar

tur. Turkish

turkm. Turkmen

tub. Tubatyва тілі

Tyng.m.. Tyngys-Manchjur

uig. Uigyr

khakh. Khakhas

chub. Chubash

yak. Yakut 